\title{
New reef-type PGE enrichment of the 2.44-Ga Junttilanniemi layered intrusion in Kainuu region, Finland
}

\author{
T. A. A. Halkoaho* and M. Niskanen \\ Geological Survey of Finland \\ *Corresponding author e-mail: tapio.halkoaho@gtk.fi
}

\begin{abstract}
Summary The Junttilanniemi layered intrusion is located in the Kainuu region, Finland. The intrusion contains three main units: marginal series, layered series and granophyre. The layered series being further divided into three megacyclic units (MCUs). Quite recently, during year 2010, Geological Survey of Finland (GTK) located from the Junttilanniemi intrusion a new reef-type platinum-group element (PGE) enrichment of the $2.44 \mathrm{Ga}$ Fennoscandian layered intrusion.
\end{abstract}

\section{Introduction and background to current research}

The Junttilanniemi layered intrusion (2444 \pm 4 Ma old, Kontinen et al., 2014), is located the municipality of Paltamo, Kainuu region, in the area of Varisniemi about $25 \mathrm{~km} \mathrm{SW}$ of the town centre and $20 \mathrm{~km} \mathrm{NW}$ from Kajaani (Fig. 1). The 1:100 $000 \mathrm{KKJ}$ map sheet containing the area is 3432. The UTM map sheet is Q5224. It is about $7.5 \mathrm{~km}$ long and 0.6 to $3 \mathrm{~km}$ wide. Its footwall rock in the eastern side is possible Archean undefined serpentinite and southern side Archean tonalitic gneiss. The hanging wall rocks in the western side are metasedimentary and metavolcanic rocks of Sumi-Sariola formation (2350-2500 Ma old). The intrusion contains three main units: marginal series, layered series and granophyre. The layered series being further divided into three megacyclic units (MCUs) (Fig. 2). The thicknesses of MCU I and MCU II are only 40-45 $\mathrm{m}$ than the MCU III is about $3600 \mathrm{~m}$ thick. The intrusion dips to the SSE at $70-85^{\circ}$. It is overturned, as the top is to the NW. The intrusion has abundant outcrops, except in its southern part, which is under a lake. Very few drillings have been performed the area of the intrusion (Mäkelä, 1974; Halkoaho and Niskanen, 2011; 2013 and Rasilainen et al., 2010). According to whole-rock compositions Junttilanniemi intrusion is analogous to the Akanvaara and Koitelainen layered intrusions, northern Finland (Fig. 1, see e.g. Mutanen, 1997).

Exploration commenced in the Junttilanniemi area in 1974 when Rautaruukki Oy drilled three diamond drill holes into the magnetite gabbro unit and one drill hole into the southwestern part of the intrusion (Mäkelä, 1974). Bedrock mapping began in the area at the end of the 1980s, when GTK started to map the area (Kontinen and Meriläinen, 2004). During 1992-1993, the Department of Geology of the University of Oulu performed some field work in the area. In 2009-2010, GTK explored the intrusion area. The main target of the exploration was to work out the Ni-Cu-PGE ore potential of the Junttilanniemi layered intrusion and find the source of the PGE-rich $(\mathrm{Cu} 0.38 \%$, Ni $0.14 \%$, Co $0.009 \%$, S $0.7 \%$, Pd 6.83 ppm, Pt 1.56 ppm and Au $0.18 \mathrm{ppm})$ gabbronorite boulder found by layman from Näätävaara area, Nurmes. During the year 2010, GTK drilled a five (5) diamond drill hole profile (totaling $563.90 \mathrm{~m}$ ) in the southern part of the Junttilanniemi layered intrusion on the ice cap of Oulujärvi (Karhusalmi area, see Fig. 2) and located a new reef-type PGE enrichment zone from the 2.44 Ga Fennoscandian layered intrusions (Halkoaho and Niskanen, 2011; 2013). 


\section{Results}

The stratigraphy of the lower part of the intrusion is completed by three ultramafic units. The border of the chromium richer and chromium poorer magma type was found between the MCU II and MCU III. Altogether five PGE enriched layers were found from the MCU I, MCU II and the lower part of MCU III, which all are associated with base metal sulfide disseminations. So high PGE-content $(\mathrm{PGE}+\mathrm{Au}=8.57 \mathrm{ppm})$ than contains the layman's boulder of Nurmes, was not found from the Junttilanniemi intrusion. The PGE richest drill hole sample (length $1 \mathrm{~m}$ ) contains PGE+Au 0.83 ppm, Cu $0.45 \%$, Ni $0.064 \%$, Co $0.006 \%$ and S $0.55 \%$ (Halkoaho and Niskanen, 2011; 2013).

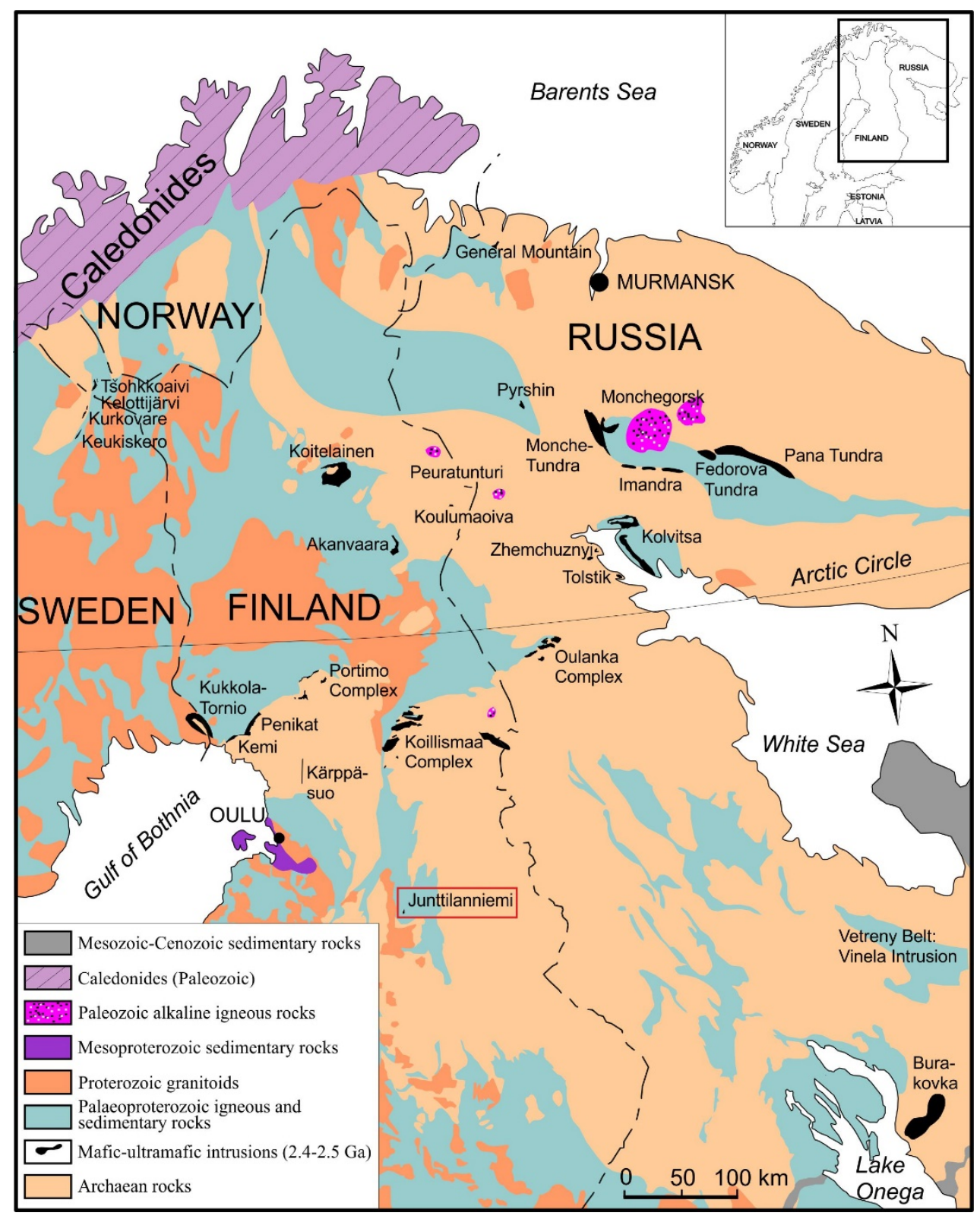

Figure 1. Simplified geological map from the part of Fennoscandian Shield, highlighting location of 2.44-2.5 Ga layered intrusions. Figure modified after Alapieti and Lahtinen (1989) and Maier et al. (2018). 


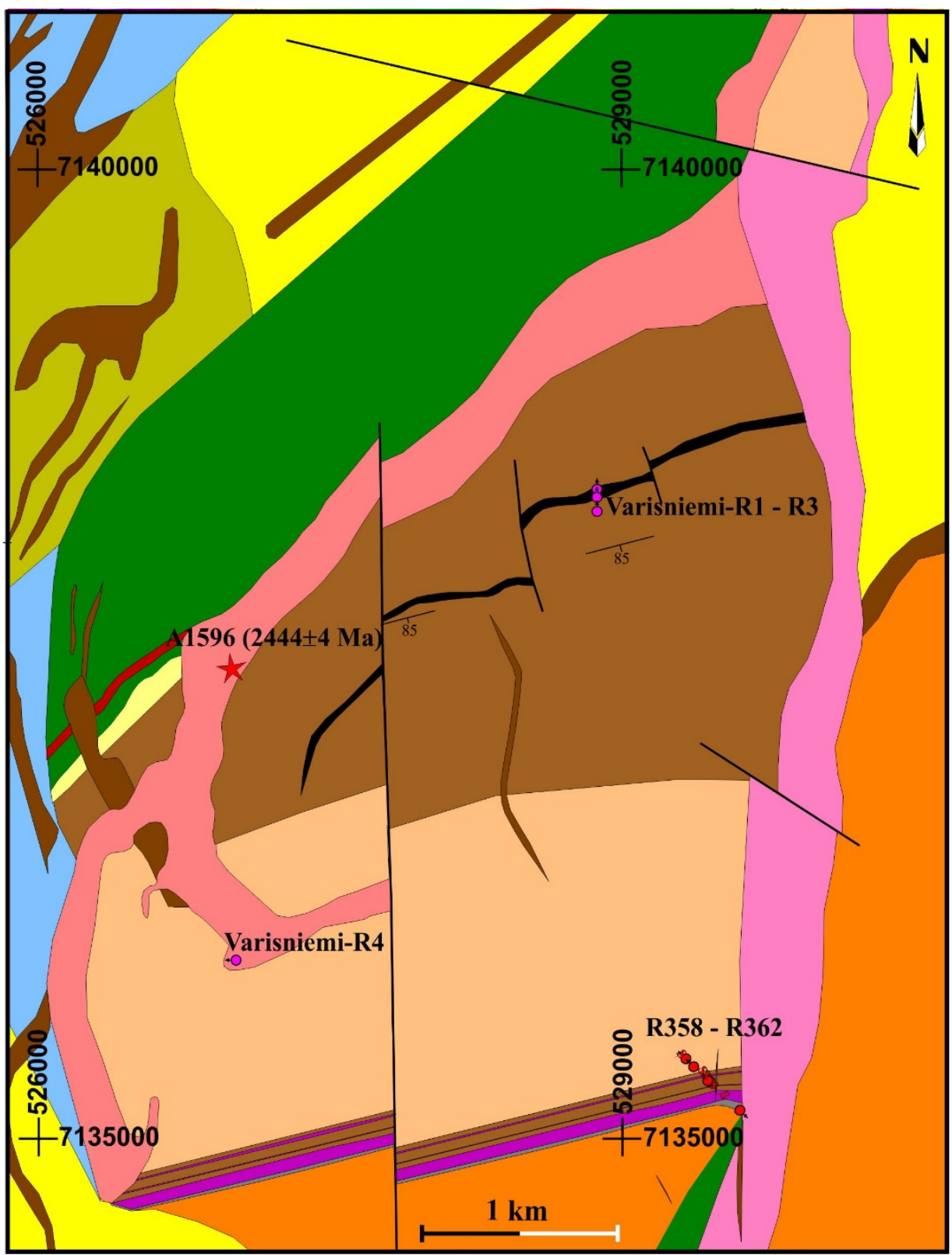

LEGEND

\begin{tabular}{|c|c|c|c|}
\hline $\begin{array}{l}\text { Tonalitic } \\
\text { migmatite }\end{array}$ & Mafic volcanic rock & $\begin{array}{l}\text { Melagabbro of the } \\
\text { marginal series }\end{array}$ & Q. Drill hole of GTK \\
\hline Quartzite & Conglomerate & $\begin{array}{l}\text { Pyroxenite }\left(\mathrm{bOCa}^{*}\right) \text { - } \\
\text { peridotite }\left(\mathrm{oOCCa}^{*} \mathrm{~b}^{*}\right)\end{array}$ & Platinum-group elements \\
\hline Siliciclastic & Felsic-intermediate & Mainly gabbroidic rocks & enriched zone \\
\hline sedimentary rock & & (pabAC or paAC) & Layering \\
\hline Mica schist & Serpentinite & anorthositic gabbro & $\star$ Age determination sample \\
\hline & Mafic dyke rock & Magnetite gabbro & $>$ Fault \\
\hline & & Granophyre & \\
\hline
\end{tabular}

Figure 2. Geological map of the Junttilanniemi layered intrusion. Modified after Kontinen and Meriläinen (2004), Rasilainen et al. (2010), Halkoaho and Niskanen (2011), and Bedrock of Finland, DigiKP - Seamless bedrock map of Finland by GTK. bOCa* = poikilitic bronzite orthocumulate with intercumulus augite, $\mathrm{oOCa}^{*} \mathrm{~b}^{*}=$ poikilitic olivine orthocumulate with intercumulus augite and bronzite, pabAC $=$ plagioclase augite bronzite adcumulate, $\mathrm{paAC}=$ plagioclase augite adcumulate and $*=$ mineral is poikilitic. 


\section{Future prospects}

Still, the layman's sample may originate from the Junttilanniemi layered intrusion, because only one cross-section of the PGE enriched zone has been made. The chromite-rich boulders found earlier from the north-northwest part of the intrusion indicate, that there is still, at least one, an undiscovered Palaeoproterozoic layered intrusion, which may also be the source of the PGErich layman's boulder. In the further study, a deep diamond drill hole from shore of the Oulujärvi is recommended. The distance from Ojaniemi to the lower contact of the intrusion is about 700 $\mathrm{m}$ and from Kuikkaniemi about $450 \mathrm{~m}$ (Halkoaho and Niskanen, 2011; 2013). In addition, exploration should be directed northwest side of the Junttilanniemi intrusion towards the municipality of Vaala, because the chromitite boulders found in the Junttilanniemi area do not originate from the Junttilanniemi layered intrusion.

\section{References:}

Alapieti TT, Lahtinen JJ (1989) Early Proterozoic layered intrusions in the northeastern part of the Fennoscandian Shield. In: Alapieti T (ed) 5th International Platinum Symposium, Guide to the Post-Symposium Field Trip, Geol. Surv. Finland, Guide 29, pp 3-41.

Bedrock of Finland - DigiKP. Digital map database [electronic resource]. Espoo: Geological Survey of Finland (referred 21 January 2021), version 2.2., available at: https://gtkdata.gtk.fi/Kalliopera/index.html

Halkoaho T, Niskanen M (2011) Tutkimustyöselostus Paltamon kunnassa varhaisproterotsooisella Junttilanniemen kerrosintruusiolla Varisniemen ja Karhusaaren välisellä alueella suoritetuista Ni-Cu-PGEmalmitutkimuksista vuosina 2007-2010. Geol. Surv. Finland, Report 1/2011, 18 pp and 7 App (in Finnish).

Halkoaho T, Niskanen M (2013) New PGE-Cu-Ni observations from the Early Palaeoproterozoic Junttilanniemi Layered Intrusion, Paltamo, eastern Finland. In: Hölttä P (ed) Current Research - GTK Mineral Potential Workshop, Rauhalahti/Kuopio, May 2012. Geol. Surv. Finland, Rep. Invest. 198, pp 29-33.

Kontinen A, Meriläinen K (2004) Paltaniemi. Geological Map of Finland 1:100,000. Pre-Quaternary Rocks. Geological Survey of Finland. Sheet 3432.

Kontinen A, Huhma H, Lahaye Y, O'Brien H (2014) The problem with the age of the Central Puolanka Group keeps fighting us. Geol. Surv. Finland, Rep. Invest. 207, pp 68-71.

Maier WD, Halkoaho T, Huhma H, Hanski E, Barnes S.-J (2018) The Penikat intrusion, Finland: Geochemistry, Geochronology, and Origin of Platinum-Palladium Reefs. J Petrol 59: 967-1006.

Mutanen T, (1997) Geology and petrology of the Akanvaara and Koitelainen mafic layered intrusions and the Keivitsa-Satovaara layered complex, northeastern Finland. Geol. Surv. Finland Bull. 395, pp 1-233.

Mäkelä K, (1974) Malminetsintätyöt Paltamossa 1974. Rautaruukki Oy, report. 7 pp and 19 App (in Finnish)

Rasilainen K, Eilu P, Halkoaho T, Iljina M, Karinen T (2010) Quantitative mineral resource assessment of nickel, copper, platinum, palladium and gold in undiscovered PGE deposits in mafic-ultramafic layered intrusions in Finland. Geol. Surv. Finland, Rep. Invest. 180, 300 pp. 